\title{
Analytical sensitivity of staining and molecular techniques for the detection of Cryptosporidium spp. oocysts isolated from bovines in water samples: a preliminary study ${ }^{\#}$
}

\author{
Sensibilidad analítica de técnicas de tinción tradicionales y una técnica molecular \\ para la detección de ooquistes de Cryptosporidium spp. aislados de bovinos \\ en muestras de agua: estudio preliminar
}

\author{
A Díaz-Lee ${ }^{\mathrm{a}}, \mathbf{R}$ Molina $^{\mathrm{a}}$, C Dougnac ${ }^{\mathrm{a}}, \mathbf{R}$ Mercado $^{\mathrm{b}}$, P Retamal $^{\mathrm{a}}$, F Fredes $^{\mathrm{a}}$ * \\ ${ }^{a}$ Department of Animal Preventive Medicine, Faculty of Veterinary and Animal Sciences, \\ Universidad de Chile, Santiago, Chile. \\ bParasitology Unit, Faculty of Medicine, Universidad de Chile, Santiago, Chile.
}

\begin{abstract}
RESUMEN
Cryptosporidium spp. es un protozoario mundialmente distribuido, que causa enfermedad digestiva en diferentes especies animales incluido el humano. Los ooquistes excretados contaminan aguas y suelos, constituyendo una amenaza para la salud pública. Debido al escaso número de ooquistes presentes en el ambiente y su reducida dosis infectante se hacen necesarios métodos rápidos y sensibles para detección en muestras ambientales. En este trabajo se comparó la sensibilidad analítica de dos técnicas de tinción, Ziehl-Neelsen modificado y Aureamina, y un PCR anidado que amplifica una región de $\sim 520$ pb del gen $18 \mathrm{~S}$ rDNA en la detección de Cryptosporidium spp. en muestras de agua. Se inocularon concentraciones conocidas de ooquistes en agua, realizando diluciones seriadas. Previa filtración se recuperaron los ooquistes para aplicación de los métodos en estudio. Los resultados demostraron que ambas tinciones tienen similar sensibilidad analítica, detectando aproximadamente ocho ooquistes/mL, mientras que el PCR anidado detectó hasta seis ooquistes $/ \mathrm{mL}$. En conclusión, dichos métodos diagnósticos, así como los protocolos de inoculación y recuperación de ooquistes, son eficaces para detección del parásito en agua, contribuyendo a la implementación de protocolos de diagnóstico estandarizados en muestras de agua ambientales.
\end{abstract}

Palabras clave: Cryptosporidium, agua, diagnóstico, Ziehl-Neelsen, Aureamina, PCR anidado.

\section{SUMMARY}

Cryptosporidium spp. is a globally distributed protozoan that causes digestive disease in different animals including humans. Excreted oocysts contaminate water and soil, constituting a public health threat. Sensitive and fast methods to detect oocysts in water samples are necessary due to the small number of oocysts present in the environment and their low infectious dose. This study compared the analytical sensitivity of two staining techniques, modified Ziehl-Neelsen and Auramine versus a nested PCR that amplifies a region of $\sim 520 \mathrm{bp}$ from $18 \mathrm{~S}$ rDNA gene, to detect Cryptosporidium spp. in water samples. Water was inoculated with oocysts using serial dilutions, and then a water filtration method was used to recover the parasite oocysts. The staining techniques had similar analytical sensitivity, detecting 8 oocysts $/ \mathrm{mL}$, while the nested PCR detected down to 6 oocysts $/ \mathrm{mL}$. In conclusion, all of these methods are effective for Cryptosporidium spp. detection in water samples, contributing to the implementation of standardized diagnostic methods for environmental water infectious agents.

Key words: Cryptosporidium, water, diagnosis, Ziehl-Neelsen, Auramine, nested PCR.

\section{INTRODUCTION}

Cryptosporidium spp. is a protozoan parasite that infects a wide range of animal species, including humans. Cryptosporidiosis is a globally distributed disease, considered as a reemerging zoonosis and it has described in all continents (Neira 2005) including Antarctic (Fredes et al 2007).

\footnotetext{
Accepted: 29.05.2014.

\# Financed by FIV 12101401.9102.006 FAVET Universidad de Chile and FONDECYT 1110255 .

* ffredes@uchile.cl
}

Faeces containing infective oocysts can reach environmental sources, particularly water and soil (Ramirez and Sreevatsan 2006). Environmental transmission routes include all vehicles with enough oocysts to produce infection, being water and food the most commonly recognized, which are a threat to public health given the nature of re-emerging zoonosis of cryptosporidiosis (Fayer 2004, Smith and Nichols 2010). The small size of the Cryptosporidium spp. oocyst (4-6 $\mu \mathrm{m})$ and its resistance to many chemical disinfectants (e.g., chlorine) makes this protozoan ideal for waterborne transmission (Carpenter et al 1999).

Contamination of drinking water with human or animal faeces has been associated with diarrhoea outbreaks caused by this parasite (Mac Kenzie et al 1994, Fayer 2004, Smith 
and Nichols 2010). Due to the description of low numbers of oocysts in environmental samples (LeChevallier et al 1991) and low infectious dose (1 to 30 oocysts) (DuPont et al 1995), fast and sensitive methods to detect oocysts in environmental samples are necessary (Fayer 2004, Ramirez and Sreevatsan 2006). The routine detection method of Cryptosporidium in faeces is carried out using direct microscopic visualization of oocysts stained by the modified Ziehl-Neelsen technique (ZN) (Ramirez and Sreevatsan 2006). Another staining method for the diagnosis of this protozoon is Auramine (AU), used mainly in human clinical samples (Smith 2008).

In water, the most widely applied diagnostic technique for the detection of oocysts is the immunofluorescence assay (IFA), but this method is labor-intensive, time-consuming, requires a large number of oocysts for positive detection and is subject to false positive and negative results (LeChevallier et al 2003, Ramirez and Sreevatsan 2006). The U.S. Environmental Protection Agency (USEPA) has developed a refinement of the IFA, termed method 1622 for detection of Cryptosporidium or method 1623 for detection of Giardia and Cryptosporidium in water. These techniques have higher efficiencies and precision, but they still suffer from the limitations of IFA (LeChevallier et al 2003).

Rapid and effective detection and monitoring methods are needed to determine the occurrence of oocysts in water sources. Development of such methods would facilitate the control and prevention of water pollution, as well as risk assessment for public health (Johnson et al 1995).

Methods based on Polymerase Chain Reaction (PCR) for detection of Cryptosporidium have been developed worldwide. These methods are more sensitive than conventional and immunological assays for detecting oocysts, including advantages such as rapid analysis of many samples, relatively low cost and the ability to discriminate between species (Johnson et al 1995, Rochelle et al 1997a, Smith 2008). The identification of Cryptosporidium species infecting humans and animals is important in determining the epidemiology of disease and transmission routes. Molecular methods targeting various genetic loci have been used for identifying Cryptosporidium species/genotypes and subtypes (Smith 2008, Xiao and Ryan 2008).

Worldwide, Cryptosporidium infection has been reported in people from 3 days to 95 years of age, but data suggest that young children are most susceptible to infection. Based on detection of oocysts in faeces, the prevalence of human infection is higher in developing than developed countries. In animals, domesticated cattle are the most thoroughly documented host species associated to distribution of Cryptosporidium infection, with the highest prevalence in pre-weaned calves (Fayer 2004).

In Chile, infections caused by Cryptosporidium spp. are endemic in humans and domestic animals, with high infection rates. Studies conducted in the Región Metropolitana showed C. parvum prevalence levels greater than $50 \%$ in diarrheic calves (Díaz-Lee et al 2011). In humans, C. parvum has been diagnosed from 3.1 to $19.3 \%$ of hospitalized children with acute diarrhoea, while in adults the prevalence was less than 3\% (Weitz and Tassara 1998). Another study showed a prevalence of $6.3 \%$ in immunocompetent and immunocompromised patients (Neira et al 2012).

Despite of this situation, in Chile there are no laboratories performing microscopic nor molecular protocols for detection of Cryptosporidium spp. in water samples. The aim of this study was to compare the analytical sensitivity of the traditional microscopic protocols and a molecular protocol, to detect the zoonotic protozoan Cryptosporidium spp. in artificially contaminated water samples.

\section{MATERIAL AND METHODS}

\section{Cryptosporidium OOCYSTS}

Oocysts were obtained from a naturally infected calf stool sample in which the agent was identified by $\mathrm{ZN}$ and confirmed by the CryptoStrip ${ }^{\mathrm{TM}}$ immunochromatographic test kit (CORIS Bioconcept) and a genus-specific PCR.

\section{OOCYST COUNTS}

In this experiment, the oocysts were counted in a Neubauer chamber (recognizing the limitations in sensitivity of the hemocytometer as a counting tool) (Ramirez and Sreevatsan 2006) resuspending $500 \mathrm{mg}$ of stool sample in $1 \mathrm{~mL}$ of distilled water and determining the initial concentration of oocysts.

\section{MICROSCOPIC TECHNIQUES}

Water sample artificial inoculation. An initial dilution of $250 \mathrm{~mL}$ of distilled water was inoculated with $1 \times 10^{6}$ oocysts, with 12-fold dilutions (see table 1).

Inoculated oocyst recovery (adapted from Nikaeen et al 2005). Inoculated water samples were filtered through a $47 \mathrm{~mm}$ diameter membrane filter with a pore size of $0.2 \mu \mathrm{m}$. The solids captured were removed by eluting in distilled water containing $0.5 \%$ Tween 20 and $0.2 \%$ sodium dodecyl sulfate (SDS). The elute was collected in a $50 \mathrm{~mL}$ conical centrifuge tube and then centrifuged at $1500 \mathrm{~g}$ for $15 \mathrm{~min}$. The supernatant was discarded and the pellet resuspended in $1 \mathrm{~mL}$ of $70 \%$ ethanol, $50 \mu \mathrm{L}$ was extracted with a micropipette and used to make two smears $(1 \times 0.5$ $\mathrm{cm}$ ) on glass slides to perform staining techniques. The procedures were done in triplicate. The positive control was a diarrheic calf stool sample positive for Cryptosporidium spp. and the negative control was distilled water without oocysts. Additionally, a filtration control was performed, using distilled water recovered after filtration.

Modified ZN staining (adapted from Smith 2008). The smear, once dry, was covered with basic fuchsin, heated to vapor emission and stained for $20 \mathrm{~min}$. Subsequently the slide was washed with tap water to remove the excess 
Table 1. Detection limit of Cryptosporidium spp. oocysts by modified Ziehl-Neelsen (ZN) and Auramine (AU) staining techniques, in distilled water samples inoculated with the agent of animal origin.

Límite de detección de ooquistes de Cryptosporidium spp. de origen animal mediante Ziehl-Neelsen modificado (ZN) y Aureamina (AU) en muestras de agua destilada inoculadas con el agente.

\begin{tabular}{rcccc}
\hline Dilution & Oocysts / 250 mL & Oocysts / $\mathrm{mL}$ & $\mathrm{ZN}$ & $\mathrm{AU}$ \\
\hline 1 & 1000000 & 4000 & + & + \\
2 & 500000 & 2000 & + & + \\
3 & 250000 & 1000 & + & + \\
4 & 125000 & 500 & + & + \\
5 & 62500 & 250 & + & + \\
6 & 31250 & 125 & + & + \\
7 & 15625 & 62.5 & + & + \\
8 & 7812 & 31.2 & + & + \\
9 & 3906 & 15.6 & + & + \\
10 & 1953 & 7.8 & + & + \\
11 & 976 & 3.9 & - & - \\
12 & 488 & 1.9 & - & - \\
\hline
\end{tabular}

dye. Acid alcohol was then added for $30 \mathrm{~s}$ and rinsed with tap water. Then the slide was covered with methylene blue for 2 to $5 \mathrm{~min}$ and rinsed in tap water. Finally, the smear was air-dried and observed in an optical microscope using the $100 x$ objective lens.

$A U$ staining (adapted from Smith 2008). A dry smear was covered with $0.3 \%$ auramine phenol stain for $10 \mathrm{~min}$. Subsequently the slide was washed with tap water, covered with acid alcohol for $30 \mathrm{~s}$ and rinsed with tap water. Finally, the slide was covered with $0.1 \%$ potassium permanganate for $30 \mathrm{~s}$ and washed with tap water. Once dry, a drop of basic glycerine was added, the slide was covered with a coverslip and observed in fluorescence microscope using the 40x objective lens.
Comparative determination of analytical sensitivity or detection limit of microscopic techniques under study. With the results obtained with the staining techniques we compared the detection limit of the two methods, expressing the results as oocysts $/ \mathrm{mL}$.

\section{MOLECULAR TECHNIQUE}

Water sample artificial inoculation. $250 \mathrm{~mL}$ of distilled water was initially inoculated with $1 \times 10^{5}$ oocysts, making 9-fold dilutions (see table 2).

Inoculated oocyst recovery (adapted from Nikaeen et al 2005). The protocol for filtration and recovery of oocysts was the same one used for microscopic techniques. However, the pellet obtained from centrifugation was resuspended in $1 \mathrm{~mL}$ of distilled water and three washes were performed with $500 \mu \mathrm{L}$ of Water for Molecular Biology ${ }^{\mathrm{TM}}$ (Merck Millipore) by centrifugation.

Disruption of the oocyst wall. Cryptosporidium sp. oocysts have a trilaminar, thick and strong wall (Fayer 2008). Therefore, prior to DNA purification a mechanical disruption of the oocyst wall was performed using zirconia silica beads $(0.1$ and $1.0 \mathrm{~mm})$ and Mini-Beadbeater-1 ${ }^{\mathrm{TM}}$ equipment in 2 cycles of $4600 \mathrm{rpm}$ for $80 \mathrm{~s}$ each.

DNA purification. DNA was purified using a High Pure PCR Template Preparation Kit ${ }^{\mathrm{TM}}$ (Roche) according to the manufacturer's instructions.

Nested PCR. In the first PCR step a fragment of $\sim 820 \mathrm{bp}$ of the $18 \mathrm{~S}$ rDNA gene was amplified with Cryptosporidium genus-specific external primers SSU-F3 (5'- GAAGGGTTGTATTTATTAGATAAA G-3') and SSU-R3 (5'-AAGGAGTAAGGAACAACCTCCA-3') (Xiao et al 1999, Muñoz et al 2011). The PCR reaction had a final volume of $15 \mu \mathrm{L}$ containing 10x PCR buffer, $1.5 \mathrm{mM}$ of $\mathrm{MgCl}_{2}, 10 \mathrm{mM}$ of each dNTP, $5 \mathrm{pM} / \mu \mathrm{L}$ of each primer, $0.75 \mathrm{U}$ of RBC Taq polymerase $\mathrm{TM}^{\mathrm{TM}}$ (RBC Bioscience) and $1 \mu \mathrm{L}$ of DNA template. Temperature

Table 2. Detection limit of Cryptosporidium spp. oocysts by conventional and nested PCR, in distilled water samples inoculated with the agent of animal origin.

Límite de detección de ooquistes de Cryptosporidium spp. de origen animal mediante PCR convencional y PCR anidado en muestras de agua destilada inoculadas con el agente.

\begin{tabular}{ccccc}
\hline Dilution & Oocysts / $250 \mathrm{~mL}$ & Oocysts / $\mathrm{mL}$ & Conventional PCR & Nested PCR \\
\hline 1 & 100000 & 400 & + & + \\
2 & 50000 & 200 & + & + \\
3 & 25000 & 100 & - & + \\
4 & 12500 & 50 & - & + \\
5 & 6250 & 25 & - & + \\
6 & 3125 & 12.5 & - & + \\
7 & 1562 & 6.2 & - & + \\
8 & 781 & 3.1 & - & - \\
9 & 390.5 & 1.6 & - & - \\
\hline
\end{tabular}


cycling was performed in a MultiGene Gradient Thermal Cycler TC9600 ${ }^{\mathrm{TM}}$ (Labnet) with an initial denaturation at $95^{\circ} \mathrm{C}$ for $5 \mathrm{~min}$ followed by 35 cycles of denaturation at $94^{\circ} \mathrm{C}$ for $45 \mathrm{~s}$, annealing at $60^{\circ} \mathrm{C}$ for $45 \mathrm{~s}$ and extension at $72^{\circ} \mathrm{C}$ for $1 \mathrm{~min}$, with final extension at $72^{\circ} \mathrm{C}$ for $10 \mathrm{~min}$. The positive control was Cryptosporidium spp. DNA from a calf stool sample, and negative control was Water for Molecular Biology ${ }^{\mathrm{TM}}$ (Merck Millipore) without oocysts.

The secondary PCR (nested) amplified a $\sim 520$ bp from $18 \mathrm{~S}$ rDNA gene of Cryptosporidium spp. using internal primers CR $18 \mathrm{~S} 3543 \mathrm{~F}$ (5'-GTTAAGTATAAACCCCTTTACAAGTATC-3') and CR18S31078R (5'-CCTCCAATCTCTAGTTGGC-3') (Muñoz et al 2011). The PCR mixture was the same as the first PCR and the amplification was performed on the same equipment, with an initial denaturation at $95^{\circ} \mathrm{C}$ for $5 \mathrm{~min}$, followed by 35 cycles of denaturation at $94^{\circ} \mathrm{C}$ for $30 \mathrm{~s}$, annealing at $55^{\circ} \mathrm{C}$ for $30 \mathrm{~s}$ and extension at $72{ }^{\circ} \mathrm{C}$ for $40 \mathrm{~s}$, and a final extension at $72^{\circ} \mathrm{C}$ for $5 \mathrm{~min}$.

PCR product detection. PCR products were analyzed by electrophoresis on a $1.5 \%$ agarose gel and stained with GelRed $^{\mathrm{TM}}$ (Biotium).

Comparative determination of analytical sensitivity or detection limit of molecular techniques. With the results of the molecular techniques we identified the detection limit of the methods, expressing the results as oocysts $/ \mathrm{mL}$.

\section{RESULTS AND DISCUSSION}

In Chile there are no laboratories performing microscopic and molecular detection protocols to identify Cryptosporidium spp. in water samples. One limitation for monitoring this parasite is that the commonly used methods are very complex and expensive to be used in routine analysis. This raises the need to find more economical and practical methods that will aid in the establishment of surveillance and control of parasite water pollution (Arnedo et al 2008). As well as cysts and oocysts of other parasitic protozoa, Cryptosporidium spp. oocysts occur in low numbers in the aquatic environment (Smith and Rose 1990). In vitro culture techniques that augment parasite numbers prior to identification are not available for protozoan parasites in drinking water, therefore large volumes of water must be sampled to detect their presence (Smith and Nichols 2010). Previous studies have reported a low number of oocysts needed to cause infection; the minimum infective dose for this parasite is 1 to 30 oocysts (DuPont et al 1995, Guerrant 1997, Okhuysen et al 1999, Fayer et al 2000, Dillingham et al 2002). Therefore it is important to be able to concentrate small numbers of oocysts effectively and to identify them accurately (Smith and Nichols 2010).

Sampling volumes between previous studies are highly variable, ranging from $15 \mathrm{~mL}$ to $1000 \mathrm{~L}$ (Ramirez and Sreevatsan 2006, Smith and Nichols 2010). This preliminary investigation used a relatively small volume (250
$\mathrm{mL}$ ) of water, to show the basic practicality of recovering Cryptosporidium oocysts and identifying them in an easily affordable water sample volume.

This study compared the analytical sensitivity of the $\mathrm{ZN}$ and $\mathrm{AU}$ staining, obtaining the minimum concentration of Cryptosporidium spp. oocysts that are required to give a positive sample (table 1). The staining techniques showed similar analytical sensitivity, as they were able to detect about 8 oocysts/mL, i.e. they detected oocyst concentrations as low as the infecting dose described for the parasite. Thus the choice of stain to use in water samples would not be based on the sensitivity of the techniques, but on the methodological advantages and disadvantages of its implementation.

Our results contradict those obtained by another study which compared the sensitivity of these microscopic techniques to detect the parasite in faeces of diarrheic calves, finding a statistically significant difference with AU staining more sensitive than ZN (Díaz-Lee et al 2011). However, the analytical results of this study are consistent with studies that analyzed stool samples from diverse domestic species by both staining techniques, finding no significant differences in sensitivity (De Quadros et al 2006, Brook et al 2008). In the case of water, one study analyzed samples of wastewater treatment plants for the detection of Cryptosporidium spp. by $\mathrm{ZN}$ and direct immunofluorescence. The agent was detected in $100 \%$ of the samples analyzed by both techniques, with $100 \%$ correspondence. Moreover, no significant difference was observed in the number of oocysts detected (Arnedo et al 2008).

Diagnostic tests based on microscopic observation of morphological features of infectious agents have the disadvantage of being operator-dependent, and the simple staining of the oocyst wall does not give any information about the viability and infectivity of the detected organism (Wiedenmann et al 1998). The main advantages of $\mathrm{ZN}$ staining are that it is inexpensive and the slides can be kept as permanent records, whereas slides with AU stain cannot (Brook et al 2008). Moreover, AU requires an expensive fluorescence microscope and background fluorescence could be a problem in AU-stained smears if there is a lot of fecal debris (Weber et al 1991). Still, if you have trained personnel and the necessary equipment to carry out the AU staining technique, it is quick and easy to read (Smith 2008).

Numerous attempts have been made to apply nucleic acid-based tests for sensitive and specific detection of Cryptosporidium oocysts in water (Rochelle et al $1997^{\mathrm{b}}$ ). Most of these protocols are based on PCR for the rapid detection of parasite oocysts in polluted water samples (Smith 2008, Zarlenga and Trout 2004), because amplification of a target gene by PCR enabled detection of low numbers of Cryptosporidium oocysts in purified samples (Johnson et al 1995, Lowery et al 2000). Moreover, a nested PCR procedure enhances the sensitivity of PCR (Nikaeen et al 2005). 
In a previous study, a PCR assay for rapid and sensitive detection of Cryptosporidium oocysts was evaluated. Serial dilutions of purified oocysts were made in distilled water samples. In one step PCR, oocyst dilutions were detected at a level of approximately $10^{2}$ oocysts, whereas with nested PCR as few as 1 oocyst could be detected, showing that performing a nested PCR may increase the detection sensitivity from 100 to 1 cell (Nikaeen et al 2005).

This study estimated the analytical sensitivity of the nested PCR, determining that 6 oocysts $/ \mathrm{mL}$ is the minimum concentration of Cryptosporidium spp. oocysts that are required to give a sample as positive, while using a conventional PCR, oocyst dilutions were detected at a level of 200 oocysts $/ \mathrm{mL}$ (table 2). The protocol utilized would accomplish the requirement to detect low levels of oocysts in water samples, given the low infective dose and low oocyst burden present in environmental samples.

This is the first national study in which these diagnostic methods are used in this distilled water matrix. At this stage it was possible to develop, standardize and compare two microscopic protocols and one molecular protocol for detecting the protozoan oocysts in artificially inoculated water samples.

The results indicate that the diagnostic methods and protocols of inoculation and recovery of oocysts are effective. Therefore, the methods could be considered as the basis for further testing of sampling methods in naturally infested waters, and molecular diagnostic protocols to determine the parasite burden and the species present in environmental samples such as surface water.

It is necessary to emphasize the importance of including the detection of Cryptosporidium spp. as a water quality indicator, either in treated or potable water, because current Chilean water quality measurement parameters do not include the search for this parasite, although its presence in drinking water involves fecal contamination and thus the presence of other contaminating microorganisms harmful to human and animal health (Smith and Nichols 2010). Therefore, their finding could be used as an indicator of quality and safety of drinking water.

\section{REFERENCES}

Arnedo I, M Bracho, O Díaz-Suárez, L Botero. 2008. Técnicas para la detección de Cryptosporidium spp. en sistemas de tratamiento de agua residual. Kasmera 36, 120-128.

Brook E, R Christley, N French, C Hart. 2008. Detection of Cryptosporidium oocysts in fresh and frozen cattle faeces: comparison of three methods. Lett Appl Microbiol 46, 26-31.

Carpenter C, R Fayer, J Trout, M Beach. 1999. Chlorine disinfection of recreational water for Cryptosporidium parvum. Emerg Infect Dis 5, 579-584.

De Quadros R, S Marques, C Amendoeira, L De Souza, P Amendoeira, C Comparin. 2006. Detection of Cryptosporidium oocysts by auramine and Ziehl Neelsen staining methods. Parasitol Latinoam 61, 117-120.

Díaz-Lee A, R Mercado, E Onuoha, L Ozaki, P Muñoz, V Muñoz, F Martínez, F Fredes. 2011. Cryptosporidium parvum in diarrheic calves detected by microscopy and identified by immunochromatographic and molecular methods. Vet Parasitol 176, 139-144.
Dillingham R, A Lima, R Guerrant. 2002. Cryptosporidiosis: epidemiology and impact. Microbes Infect 4, 1059-1066.

DuPont H, C Chappell, C Sterling, P Okhuysen, J Rose, W Jakubowski. 1995. The Infectivity of Cryptosporidium parvum in Healthy Volunteers. N Engl J Med 332, 855-859.

Fayer R, U Morgan, S Upton. 2000. Epidemiology of Cryptosporidium: transmission, detection and identification. Int J Parasitol 30, 1305-1322.

Fayer R. 2004. Cryptosporidium: a water-borne zoonotic parasite. Vet Parasitol 126, 37-56.

Fayer R. 2008. General Biology. In: Fayer R, Xiao L (eds). Cryptosporidium and cryptosporidiosis. $2^{\text {nd }}$ ed. CRC Press, Boca Ratón, USA, Pp 1-42.

Fredes F, E Raffo, P Muñoz. 2007. First report of Cryptosporidium spp. oocysts in stool of Adélie penguin from the Antarctic using acid-fast stain. Antarct Sci 19, 437-438.

Guerrant R. 1997. Cryptosporidiosis: An Emerging, Highly Infectious Threat. Emerg Infect Dis 3, 51-57.

Johnson D, N Pieniazek, D Griffin, L Misener, J Rose. 1995. Development of a PCR protocol for sensitive detection of Cryptosporidium oocysts in water samples. Appl Environ Microbiol 61, 3849-3855.

LeChevallier M, W Norton, R Lee. 1991. Occurrence of Giardia and Cryptosporidium spp. in surface water supplies. Appl Environ Microbiol 57, 2610-2616.

LeChevallier M, G Di Giovanni, J Clancy, Z Bukhari, S Bukhari, J Rosen, J Sobrinho, M Frey. 2003. Comparison of Method 1623 and Cell Culture-PCR for Detection of Cryptosporidium spp. in Source Waters. Appl Environ Microbiol 69, 971-979.

Lowery C, J Moore, B Millar, D Burke, K McCorry, E Crothers, J Dooley. 2000. Detection and speciation of Cryptosporidium spp. in environmental water samples by immunomagnetic separation, PCR and endonuclease restriction. J Med Microbiol 49, 779-785.

Mac Kenzie W, N Hoxie, M Proctor, M Gradus, K Blair, D Peterson, J Kazmierczak, D Addiss, K Fox, J Rose, J Davis. 1994. A massive outbreak in Milwaukee of Cryptosporidium infection transmitted through the public water supply. N Engl J Med 331, 161-167.

Muñoz P, F Fredes, A Díaz-Lee, R Mercado, L Ozaki. 2011. Detección de Cryptosporidium spp. en terneras de lecherías de la Región Metropolitana mediante Ziehl Neelsen y confirmada por inmunocromatografía y ensayo molecular. Arch Med Vet 43, 111-116.

Neira P. 2005. Acerca de Cryptosporidium spp. en Chile. Rev Méd Chile $133,847-849$.

Neira O, N Muñoz, G Wilson, M Barthel, M Rosales, C Henríquez. 2012. Especies de Cryptosporidum spp. en pacientes inmunodeficientes e inmunocompetentes de Valparaíso: Estudio descriptivo. Rev Chil Infectol 29, 63-71.

Nikaeen M, A Mesdaghinia, M Jeddi, M Rezaeian, K Makimura. 2005. A nested-PCR assay for detection of Cryptosporidium parvum oocysts in water samples. Iran J Public Health 34, 13-18.

Okhuysen P, C Chappell, J Crabb, C Sterling, H DuPont. 1999. Virulence of three distinct Cryptosporidium parvum isolates for healthy adults. J Infect Dis 180, 1275-1281.

Ramírez N, S Sreevatsan. 2006. Development of a sensitive detection system for Cryptosporidium in environmental samples. Vet Parasitol 136, 201-213.

Rochelle P, R De León, M Stewart, R Wolfe. 1997ª Comparison of primers and optimization of PCR conditions for detection of Cryptosporidium parvum and Giardia lamblia in water. Appl Environ Microbiol 63, 106-114.

Rochelle P, D Ferguson, T Handojo, R De León, M Stewart, R Wolfe. $1997^{\mathrm{b}}$. An assay combining cell culture with reverse transcriptase PCR to detect and determine the infectivity of waterborne Cryptosporidium parvum. Appl Environ Microbiol 63, 2029-2037.

Smith H, J Rose. 1990. Waterborne cryptosporidiosis. Parasitol Today $6,8-12$.

Smith H. 2008. Diagnostics. In: Fayer R and Xiao L (eds). Cryptosporidium and cryptosporidiosis. $2^{\text {nd }}$ ed. CRC Press, Boca Ratón, USA, Pp 173-207. 
Smith H, R Nichols. 2010. Cryptosporidium: Detection in water and food. Exp Parasitol 124, 61-79.

Weber R, R Bryan, H Bishop, S Wahlquist, J Sullivan, D Juranek. 1991 Threshold of detection of Cryptosporidium oocysts in human stool specimens: evidence for low sensitivity of current diagnostic methods. J Clin Microbiol 29, 1323-1327.

Weitz J, R Tassara. 1998. Criptosporidiosis. En: Atías A (ed). Parasitología Médica. Mediterráneo, Santiago, Chile, Pp 146-151.

Wiedenmann A, P Krüger, K Botzenhart. 1998. PCR detection of Cryptosporidium parvum in environmental samples-a review of published protocols and current developments. J Ind Microbiol Biotechnol 21, 150-166.

Xiao L, L Escalante, C Yang, I Sulaiman, A Escalante, R Montali, R Fayer, A Lal. 1999. Phylogenetic analysis of Cryptosporidium parasites based on the small-subunit rRNA gene locus. Appl Environ Microbiol 65, 1578-1583.

Xiao L, U Ryan. 2008. Molecular Epidemiology. In: Fayer R, L Xiao (eds). Cryptpsporidium and Cryptosporidiosis. $2^{\text {nd }}$ ed. CRC Press, Boca Ratón, USA, Pp 119-172.

Zarlenga D, J Trout. 2004. Concentrating, purifying and detecting waterborne parasites. Vet Parasitol 126, 195-217. 